\title{
Effects of Euphorbia milii latex on mitogen-induced lymphocyte proliferation
}

\author{
DELGADO I.F. ${ }^{1 *}$; PAUMGARTTEN F.J.R. ${ }^{2}$
}

${ }^{1}$ Vice Directory of Research, Teaching and Strategic Issues, National Institute of Quality Control in Health, Oswaldo Cruz Foundation, Av. Brasil, 4365, 21.040-900, Manguinhos, Rio de Janeiro, Brazil. E-mail: isabella.delgado@ incqs.fiocruz.br ${ }^{2}$ Laboratory of Environmental Toxicology, Department of Biological Sciences, National School of Public Health, Oswaldo Cruz Foundation, Av. Brasil, 4365, 21.040-900, Manguinhos, Rio de Janeiro, Brazil.

\begin{abstract}
The crude latex of "Crown-of-Thorns" (Euphorbia milii var hislopii, syn E.splendens) is a potent plant molluscicide. For this reason, toxicological studies have been performed to evaluate the health risks posed by its use in schistosomiasis control programs. The present study is part of a more comprehensive immunotoxicological evaluation of this molluscicide. Here, we investigated the effects of $E$. milii latex on the proliferation of human lymphocytes in vitro. Lyophilized latex of $E$. milii $(0,0.5,5,25$ and $50 \mu \mathrm{g} / \mathrm{ml})$ was incubated with whole blood in the presence of proliferation stimulators, i.e. lectins (phytohemagglutinin, concanavalin A and pokeweed mitogen), as well as with human monoclonal antibody against $\mathrm{CD} 3$ and tetanus toxoid. Cell proliferation was measured by ${ }^{3} \mathrm{H}$-thymidine incorporation, and the effects of latex on mitogen-induced cell proliferation were compared to the effects of $10 \mathrm{ng} /$ $\mathrm{ml}$ of 12-O-tetradecanoylphorbol-13-acetate (TPA). Results showed that mitogen-induced cell proliferation was markedly enhanced by $E$. milii latex. This synergistic effect of latex on mitogeninduced lymphocyte proliferation may be due to the presence of TPA-like phorbol esters and/ or to mitogenic plant lectins.
\end{abstract}

Keywords: Euphorbiaceae, plant molluscicides, phorbol esters, lymphocyte activation.

RESUMO: Efeito do latex de Euphorbia milii sobre a proliferação de linfócitos induzida por mitogénio. O látexbrutoda "Coroa de Cristo" (Euphorbia miliivarhislopii, syn E.splendens) é um potente moluscicidavegetal. Neste sentido, são necessários estudos toxicológicosque visemavaliar possíveis riscos à saúdeassociados ao uso em larga escala desta espécie em áreas endêmicas para esquistossomose. O presente estudo é parte deuma avaliação mais abrangentesobre o potencial tóxico destemoluscicida. Foram investigados in vitro osefeitos dolátex da E.miliisobre a proliferação delinfócitoshumanos. O látexliofilizado ( 0 ; 0,$5 ; 5 ; 25$ e $50 \mu \mathrm{g} / \mathrm{ml}$ )foi incubado comsangue totalna presençade agentes mitogênicos, tais como lectinas(fitohemaglutinina, concanavalina Ae pokeweed), anticorpomonoclonalhumano antiCD3etoxóide tetânico. A proliferação celularfoi quantificada atravésincorporaçãode ${ }^{3} \mathrm{H}$-timidina eos efeitos do látexnaproliferação celular induzida por agentes mitogênicosforam comparados comos efeitos de10 ng/mlde12-O-tetradecanoilforbol-13-acetato (TPA). Os resultados demonstram quea proliferação celular induzida poragentes mitogênicosfoimarcadamenteaumentada na presença do látex daE.milii.Oefeito sinérgico observado pode ser devidoà presença deésteres de forbol, como o TPA, e/oude lectinas com ação mitogênica presentes nesta espécie vegetal.

Palavras-chave:Euphorbiaceae, moluscicidas vegetais, ésteres de forbol, ativação de linfócitos.

\section{INTRODUCTION}

Schistosomiasis is a major public health problem in Brazil as well as in several African and Asian countries. It has been estimated that 200 million people are infected with Schistosomatrematodes all over the world and that 600 million people are at risk in endemic areas (WHO, 1993; Gryseels et al., 2006). Since the intermediate hosts of Schistosomatrematodes are freshwater mollusks, snail control by mollusciciding has been one of the methods of choice for the control of transmission of this parasitic disease (WHO, 1993).

In quest of safer, more selective and cheaper molluscicides, hundreds of botanical species have been screened for molluscicidal activity in recent years. Within this context, the latex of "Crown-of-Thorns" (Euphorbia milii Des Moul. ex 
Boissvarhislopii, synE.splendens) has proved to be one of the most promising plant molluscicides tested so far (Vasconcellos\&Schall, 1986; Mendes et al., 1992; Afonso-Neto et al., 2010). It is active against mollusks which are intermediate hosts of Schistosomatrematodes at concentrations as low as $0.5 \mathrm{ppm}$ in the laboratory and at concentrations as low as $5.0 \mathrm{ppm}$ under field conditions (Vasconcellos\&Schall, 1986; Mendes et al., 1992). Besides its remarkable potency, E. milii latex also presents other advantages as a molluscicide: $E$. milii can be easily cultivated in endemic areas and yields a rather large amount of latex throughout the year, no marked seasonal nor geographic variation have been found in the molluscicidal activity, and the latex has proved to be less harmful to nontarget organisms than niclosamide, today's mostly used synthetic molluscicide (Baptista et al., 1994; Schall et al., 1992; Oliveira-Filho et al., 2000; Yadav \&Jagannadham, 2008; Oliveira-Filho et al., 2010; Mello-Silva et al., 2011).

Since E. milii crude latex, in natura or lyophilized, proved to be a very potent plant moluscicide, its toxicity to mammals and other non-target species has been comprehensively studied. The undiluted latex of $E$. milii was found to be irritant to mammalian skin and eyes (Freitas et al., 1997), but no evidence was found that it is genotoxic (Zamith et al., 1996; Delgado et al., 2003) or teratogenic (Souza et al., 1997).

The present study was undertaken to investigate the effects of $E$. milii latex on the proliferation of human lymphocytes in vitro. It is part of a more comprehensive evaluation of the effects of this plant molluscicide on the immune system under way at our laboratory.

\section{MATERIALS AND METHODS}

Latex of E. milii var. hislopii was obtained from plants grown in experimental gardens located within Fiocruz campus, Rio de Janeiro, Brazil. Plant identification was made by a botanist (Dr. Ivete Maria da Silva), and a voucher specimen (reference number R202859) was deposited in the herbarium of the National Museum of the Federal University of Rio de Janeiro (UFRJ), Rio de Janeiro, Brazil. A longitudinal incision was made in the plant stem and the latex was collected into glass tubes which were sealed, wrapped in aluminum foil, and immediately transported to the laboratory where it was lyophilized. Lyophilized latex was protected from light and stored in the refrigerator $\left(2^{\circ}-6^{\circ} \mathrm{C}\right)$ until use. It has been demonstrated that, under these storage conditions, the molluscicidal activity of latex is stable for at least 18 months (Schall et al., 1992).

Human blood sample was obtained from a healthy donor by vein-puncture. 50 IE of heparin (Seromed, Berlin) was added per $\mathrm{ml}$ blood and syringes were gently rotated several times at room temperature. The blood sample was then diluted $(1+7)$ with RPMI 1640 medium (Seromed, Berlin) supplemented with $5 \%$ heat-inactivated fetal calf serum (FCS, microplasma, virus, bacteriophage, and endotoxin tested, Seromed, Berlin) and 2.5\% L-glutamine (Seromed, Berlin). The proliferation stimulators were diluted in RPMI medium: 40 $\mu \mathrm{g} / \mathrm{ml}$ of phytohemagglutinine (PHA-E), $20 \mu \mathrm{g} /$ $\mathrm{ml}$ of concanavalin $\mathrm{A}(\mathrm{CON}-\mathrm{A})$ and pokeweed mitogen (PWM), $2.5 \mu \mathrm{g} / \mathrm{ml}$ of human monoclonal antibody against CD3 (anti-CD3), and $10 \mu \mathrm{g} / \mathrm{ml}$ of tetanus toxoid. Round-bottomed 96 well culture plates (NuncMicrowell, Nunc $\mathrm{GmbH}$, Wiesbaden) were used. The wells were pipetted (in triplicate) with mitogens, mitogens in addition to different concentrations of latex $(0.5,5,25$ and $50 \mu \mathrm{g} /$ $\mathrm{ml}$ ), or with mitogens in addition to $10 \mathrm{ng} / \mathrm{ml}$ of 12-O-tetradecanoylphorbol-13-acetate (TPA). In all these cases the volume pipetted into each well was $100 \mu \mathrm{l}$. The same volume of diluted blood was added to the wells. Culture was performed for 6 days at $37^{\circ} \mathrm{C}$ in air plus $5 \% \mathrm{CO}_{2}$. Six hours prior to the end of the culture period, $10 \mu$ l of ${ }^{3} \mathrm{H}$-thymidine (Amersham, $1 \mathrm{mCi} / \mathrm{ml}$ ) in aqueous solution was added to each well. At the end of the culture period, the plates were emptied by aspiration with a cell harvester (Titertek $^{\circledR}$, Flow Laboratories), washed and filtered through a cell-culture filter (Skatron Instruments, UK). The filters (one per sample) were dried and subsequently placed into $20 \mathrm{ml}$ polyethylene vials (Zinsser Analytic, Frankfurt) containing $10 \mathrm{ml}$ of scintillation fluid (Quick Safe ${ }^{\circledR}$ Zinsser Analytik). ${ }^{3} \mathrm{H}$ disintegrations were measured for 5 minutes with a scintillation counter (Tricarb ${ }^{\circledR}$, Packard) and values are given as counts per minutes (cpm).

\section{RESULTS}

The effects of $E$. milii latex on mitogeninduced stimulation of DNA synthesis in human lymphocytes are shown in Figure 1 (lectins: PHA-E, CON-A and PWM) and Figure 2 (anti-CD3 monoclonal antibody and tetanus toxoid).

As can be seen in Figure 1A, the crude latex of $E$. milii caused a dose-dependent increase in ${ }^{3} \mathrm{H}$-thymidine incorporation in cells stimulated with PHA-E. A 3-fold increase was already observed at the lowest concentration of latex tested $(5 \mu \mathrm{g} /$ $\mathrm{ml})$. At higher concentrations of latex $(50 \mu \mathrm{g} / \mathrm{ml})$, a 4-fold increase in ${ }^{3} \mathrm{H}$-thymidine incorporation was observed. The increase in PHA-E-induced lymphocyte proliferation stimulated by $E$. milii latex was more pronounced than that observed with 10 $\mathrm{ng} / \mathrm{ml}$ of TPA. 
A

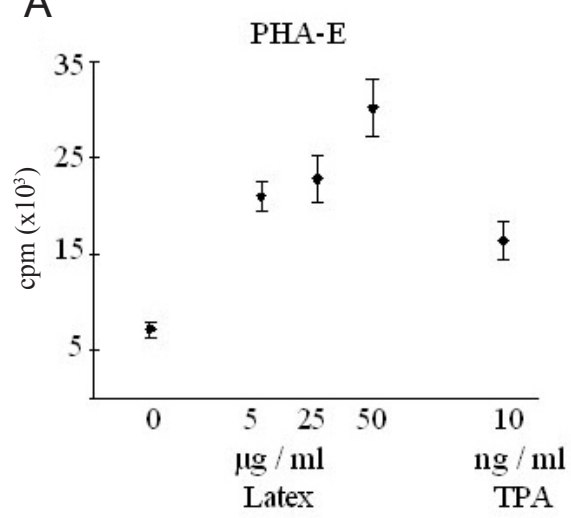

I mean $\pm \mathrm{SD}$

PWM

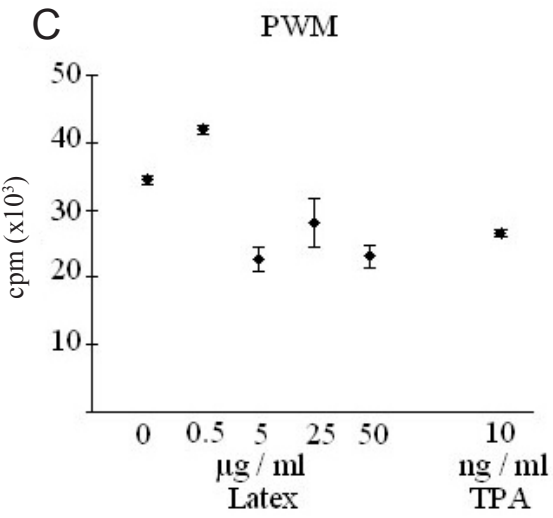

FIGURE 1. Effects of $E$. milii latex on the stimulation of human lymphocytes with PHA-E CON-A and PWM. The extent of stimulation was measured as ${ }^{3} \mathrm{H}$-thymidine incorporation, and results are shown as counts per minute (cpm). Cells were stimulated with different lectins in the presence of latex $(0.5,5,25$ and $50 \mu \mathrm{g} / \mathrm{ml})$ or TPA (10 $\mathrm{ng} / \mathrm{ml})$. Values are mean $\pm \mathrm{SD}$.

The proliferative response of cells stimulated with CON-A was increased in the presence of $E$. milii latex as well (Figure 1B). A 2-fold increase in ${ }^{3} \mathrm{H}$-thymidine incorporation was already noted with the lowest concentration of latex tested $(0.5 \mu \mathrm{g} /$ $\mathrm{ml})$. However, the effects of higher concentrations of latex $(25$ and $50 \mu \mathrm{g} / \mathrm{ml})$ were only slightly more pronounced. The lymphocyte proliferation was higher in the presence of E. milii latex and CON-A than in the presence of $10 \mathrm{ng} / \mathrm{ml}$ of TPA and CON-A.

The effects of latex on PWM-induced cell proliferation are shown in Figure 1C. At the lowest concentration tested $(0.5 \mu \mathrm{g} / \mathrm{ml})$, E. milii latex caused an increase in ${ }^{3} \mathrm{H}$-thymidine incorporation when present together with PWM. However, higher concentrations of latex $(5,25$ and $50 \mu \mathrm{g} / \mathrm{ml})$ decreased the proliferative response in a similar way as $10 \mathrm{ng} / \mathrm{ml}$ of TPA.

It is obvious that PWM per se caused a very intense mitogenic response. While ${ }^{3} \mathrm{H}$-thymidine incorporation after stimulation with PHA-E alone (Figure $1 \mathrm{~A}$ ) or CON-A alone (Figure $1 \mathrm{~B}$ ) reached values as high as $6.0 \times 10^{3} \mathrm{cpm}$, values found after stimulation with PWM alone (Figure 1C) were almost
6 -fold higher $\left(35.0 \times 10^{3} \mathrm{cpm}\right)$. Thus, a possible explanation for the reduction in ${ }^{3} \mathrm{H}$-thymidine incorporation observed when cells were costimulated with PWM and latex at concentrations > $5 \mu \mathrm{g} / \mathrm{ml}$, or TPA (10 $\mathrm{ng} / \mathrm{ml}$ ), is medium exhaustion. Since PWM per se induced a strong proliferative response, co-stimulation with PWM and latex (or TPA) may have lead to an extremely high rate of cell divisions. Under those circumstances, the volume of nutrient medium contained in the wells might have been insufficient to maintain such rapid proliferation rates for a period of incubation as long as 6 days. In this case, the higher the initial proliferative response, the faster the nutrient exhaustion and the lower the cell proliferation rate at the end of the incubation period when ${ }^{3} \mathrm{H}$-thymidine incorporation was measured.

The results show that the presence of $E$. milii latex adds to the effects of the mitogeniclectins tested. The plant lectins are rather unspecific stimulators of lymphocyte proliferation. PWM seems to be the least specific one, stimulating all types of $T$ cells. CON-A and PHA-E are believed to stimulate predominantly supressor / cytotoxic cells and helper 
T-cell subsets, respectively (Ling \& Kay, 1975).

In contrast to the lectins, anti-CD3 monoclonal antibody and tetanus toxoid antigen are highly selective mitogenic agents that are recognized by specific receptor sites present in a limited number of lymphocytes (Ling \& Kay, 1975).

As shown in Figure 2A, E. milii latex also increases cell proliferation in the presence of antiCD3. In this case, the proliferation stimulator (antiCD3 monoclonal antibody) per se had a relatively weak effect on DNA synthesis, but a 10-fold increase in ${ }^{3} \mathrm{H}$-thymidine incorporation was observed when cells were co-stimulated with latex $(5 \mu \mathrm{g} / \mathrm{ml})$. The effect of latex on lymphocyte proliferation in the presence of anti-CD3 was less pronounced at concentrations higher than $5 \mu \mathrm{g} / \mathrm{ml}$. The effect of TPA (10 ng/ml) on anti-CD3-induced lymphocytes was less pronounced than that produced by 5 and $25 \mu \mathrm{g} / \mathrm{ml}$ of latex.

A co-stimulation by $E$. milii latex was also observed in the presence of tetanus toxoid (Figure 2B). ${ }^{3} \mathrm{H}$-thymidine incorporation was increased from approximately $2.0 \times 10^{3} \mathrm{cpm}$ (cells stimulated with tetanus toxoid only) to more than $30.0 \times 10^{3} \mathrm{cpm}$ when cells were co-stimulated with latex at a concentration as high as $25 \mu \mathrm{g} / \mathrm{ml}$. TPA ( $10 \mathrm{ng} / \mathrm{ml}$ ) did not increase tetanus toxoid-induced cell proliferation.

\section{DISCUSSION}

The data reported in this paper suggest that the crude latex of $E$. milii contains substances able to enhance lymphocyte proliferation in vitro. The co- mitogenic effect of latex was observed both in the presence of the relatively unspecific stimulators, i.e. plant lectins such as PHA-E, CON-A and PWM, as well as of the highly selective stimulators, i.e. antigens such as anti-CD3 monoclonal antibody and tetanus toxoid.

The effect of latex on mitogen-induced cell proliferation may have been due to the presence of phorbol esters. These compounds have been found in Euphorbiaceae plants and some of them are known to possess in vitro and in vivomitogenic activity. On the other hand, the presence of mitogeniclectinscan not be excluded. Although mitogenic-lectins have been obtained mainly from seeds of legumes, some authors have suggested that latices or saps of members of Euphorbiaceae(Premaratna et al., 1981), and other plants are also useful sources for the purification of lectins. In the Euphorbiaceaefamily, lectins seem to be preferentially found in their latices (Linier et al., 1986). Non-mitogeniclectins were purified from E. neriifolia (Seshagirirao et al., 1995) and H.creptans (Barbieri et al., 1983) and mitogeniclectins were isolated from the crude latex of $E$. characias (Barbieri et al., 1983) and E. marginata (Stirpe et al., 1993). However, as far as we are aware, no data on the presence of lectins in Euphorbia milii is available in the literature.

TPA as well as lectinsare well-known to be potent allergens. The demonstration of a strong lymphocyte-proliferation capacity of the $E$. milii latex is consistent with the assumption of allergizing components being present in this molluscicidal latex. This could pose a health risk to humans when a sufficient contact with such components occurs. Since our studies were performed with a

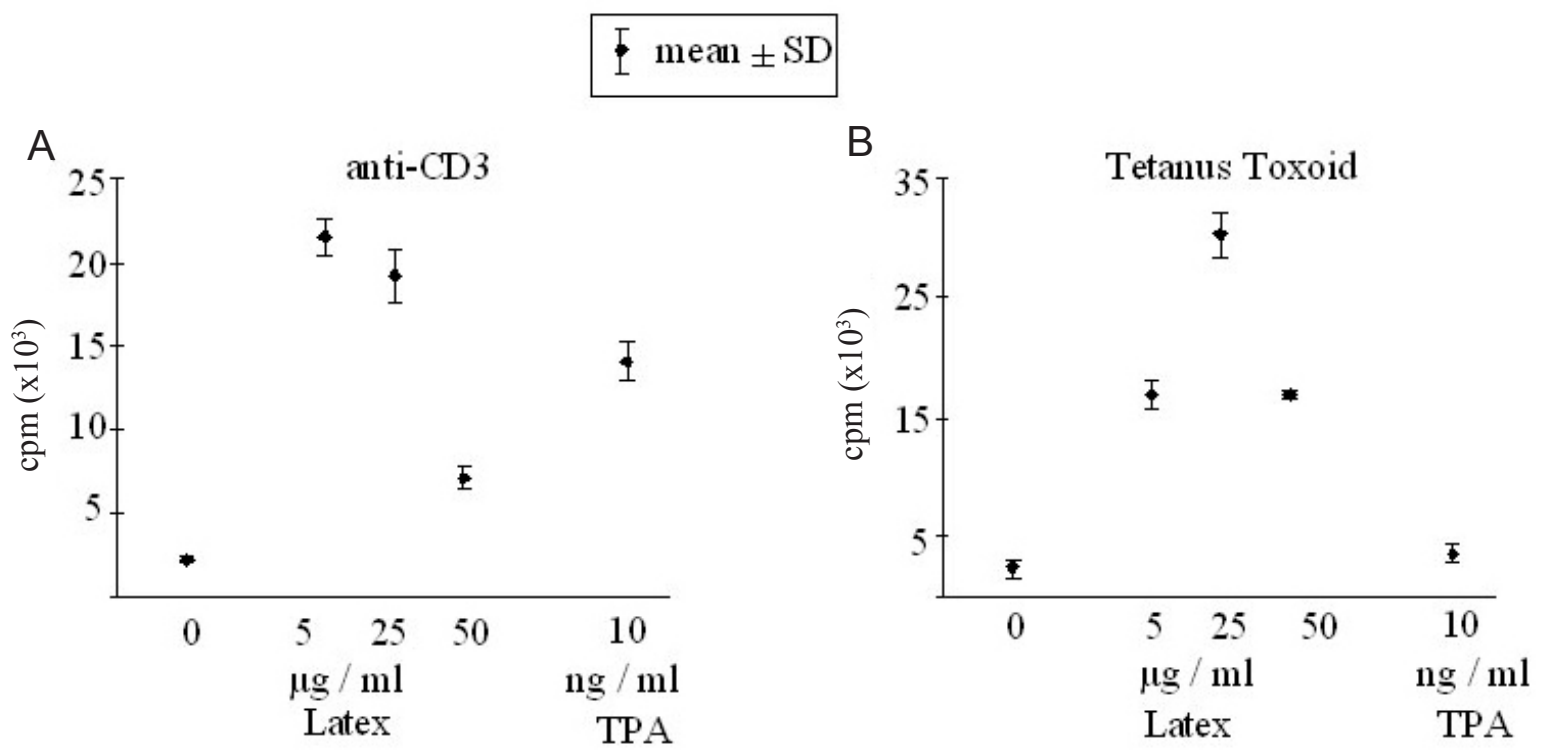

FIGURE 2.Effects of E. milii latex on the stimulation of human lymphocytes with anti-CD3 and tetanus toxoid. The extent of stimulation was measured as ${ }^{3} \mathrm{H}$-thymidine incorporation, and results are shown as counts per minute (cpm). Cells were stimulated with the different mitogens in the presence of latex $(0.5,5,25$ and $50 \mu \mathrm{g} /$ $\mathrm{ml}$ ) or TPA (10 $\mathrm{ng} / \mathrm{ml})$. Values are mean $\pm \mathrm{SD}$. 
crude preparation of $E$. milii latex, no information on the quality and quantity of components active in stimulating lymphocyte proliferation is available. Further studies are needed with defined components of $E$. milii latex. If such components can be identified (and if they are not identical with the molluscicidal principle), it might be attempted to prepare an antigen-free plant molluscicide product, in the future.

\section{ACKNOWLEDGMENTS}

This work was supported by grants from CNPq and PAPES/FIOCRUZ. Isabella F. Delgado and Francisco J. R. Paumgartten are recipients of Productivity Research fellowships - CNPq.

\section{REFERENCE}

Afonso-Neto, I.S.; BESSA, E.A.; SOARES, G.L.G. Avaliação da atividade moluscicida do látex de três espécies de Euphorbia (Euphorbiaceae) sobre Le ptinariaunilamellataO'Orbigny, 1835 (Gastropoda - Subulinidae). Revista Brasileira de Plantas Medicinais. v.12, p.90-5, 2010.

BAPTISTA, D.F.; VASCONCELLOS, M.C.; LOPES, F.E.; SILVA, I.P.; SCHALL, V.T. Perspectives ofusingEuphorbiasplendes as a moluscicide in schistosomiasiscontrolprograms. Southeast Asian Journal of Tropical Medicine and Public Health, v.25, p.419-24, 1994.

BARBIERI, L.; FALASCA, A.; FRANCESCHI, C.; LICASTRO, F.; ROSSI, C.A.; STIRPE, F.. Purification and properties of two lectins from the latex of the euphorbiaceous plants Huracrepitans L. (sand-box tree) and Euphorbia characias L. (Mediterranean spurge). Biochemical Journal, v.215, p.433-39, 1983.

DELGADO, I.F.; DE-CARVALHO, R.R.; DE-OLIVEIRA, A.C.A.X.; KURIYAMA, S.N.; OLIVEIRA-FILHO, E.C.; SOUZA, C.A.M.; PAUMGARTTEN, F.J.R. Absence of tumor promoting activity of Euphorbia milii latex on the mouse back skin. Toxicology Letters, v.145, p.17580, 2003.

FREITAS, J.C.B.R.; PRESGRAVE, O.A.F.; FINGOLA, F.F.; MENEZES, M.A.C.; VASCONCELLOS, M.C.; SCHALL, V.T.; PAUMGARTTEN, F.J.R. Toxicological study of the molluscicidal latex of Euphorbia splendens: irritant action on skin and eye.Memórias do Instituto Oswaldo Cruz, v.86, p.87-8, 1991.

GRYSEELS, B.; POLMANK, K.; CLERINX, J.; KESTENS, L. Human Schistosomiasis. The Lancet, v.368, p.110618, 2006.

LIENER, I.E.; SHARON, N.; GOLSTEIN, I.J.The Lectins: Propeties, Functions and Applications in Biology and Medicine. Orlando: Academic Press, 1986. 600p.

LING, N.R.; KAY, J.E.Lymphocyte stimulation. Amsterdam, Oxford: North-Holland Publishing Company, 1975. 398p. MELLO-SILVA, C.C.; VASCONCELLOS, M.C.; BEZERRA, J.C.B.; RODRIGUES, M.L.A.; PINHEIRO, J. The influence of exposure to Euphorbia splendes var. hislopii latex on the concentration of total proteins and nitrogen products in Biomphalariaglabrata infected with Schistosomamansoni. ActaTropica, v.117, p.101-4, 2011.

MENDES, M.M.; BAPTISTA, D.F.; VASCONCELLOS, M.C.; SCHALL, V.T. Evaluation of the molluscicidal properties of Euphorbia splendens var. hislopii (N.E.B.) (Euphorbiaceae) - 1.Experimental test in a lentic habitat. Memórias do Instituto Oswaldo Cruz, v.87, p.21-3, 1992.

PREMARATNA, A.; SHADAKSHARRASWAMY, M.; NANJAPPA, S. Isolation, purification \& properties of a lectin from the latex of Synadeniumgrantii Hook f.Indian Journal of Biochemistry and Biophysics, v.18, p.325, 1981.

OLIVEIRA-FILHO, E.C.; PAUMGARTTEN, F.J.R. Toxicity of Euphorbia milii latex and niclosamide to snails and nontarget aquatic species.Ecotoxicology and Environmental Safety, v.46, p.342-50, 2000.

OLIVEIRA-FILHO, E.C.; GERALDINO, B.R.; COELHO, D.R.; DE-CARVALHO, R.R.; PAUMGARTTEN, F.J.R. Comparative toxicity of Euphorbia milii latex and synthetic molluscicidesto Biomphalariaglabrata embryos. Chemosphere, v.81, p.218-27, 2010.

SCHALL, V.T.; VASCONCELLOS, M.C.; VILLAÇACOELHO, A.L.; FERREIRA-LOPES, F.E.; PAZDA-SILVA, I. Evaluation of temporal, seasonal and geographic stability of the molluscicidal property of Euphorbia splendes latex. Revista do Instituto de Medicina Tropical de São Paulo, v.34, p.183-91, 1992. SESHAGIRIRAO, K.; PRASAD, M.N. Purification and partial characterization of a lectin from Euphorbia neriifolia latex.Biochemistry \&Molecular Biology International, v.35, p.1199-204, 1995.

SOUZA, C.A.M.; DE-CARVALHO, R.R.; KURIYAMA, S.N.; ARAUJO, I.B.; RODRIGUES, R.P.; VOLLNER, R.S.; ALVES, E.N.; PAUMGARTTEN, F.J.R. Study of the embryofeto-toxicity of "Crown-of-Thorns" (Euphorbia milli) latex, a natural molluscicide. Brazilian Journal of Medicine and Biological Research, v.30, p.132532, 1997.

STIRPE, F.; LICASTRO, F.; MORINI, M.C.; PARENTE, A.; SAVINO, G.; ABBONDANZA, A.; BOLOGNESI, A.; FALASCA, A.I.; ROSSI, C.A. Purification and partial characterization of a mitogeniclectin from the latex of Euphorbia marginata. BiochimicaetBiophysicaActa, v.1158, p.33-9, 1993.

VASCONCELLOS, M.C.; SCHALL, V.T. Latex of "Coroa-de-Cristo" (Euphorbia splendes): an effective molluscicide. Memórias do Instituto Oswaldo Cruz, v.81, p.475-6, 1986.

WORLD HEALTH ORGANIZATION - WHO. The control of Schistosomiasis: second report of the WHO Expert Committee. WHO Technical Report, Series 830, Geneva, Switzerland, 1993, 86p.

YADAV, S.C.; JAGANNADHAM, M.V. Physiological changes and molluscicidal effects of crude latex and milin on Biomphalariaglabrata.Chemosphere, v.71, p.1295-1300, 2008.

ZAMITH, H.P.S.; PAUMGARTTEN, F.J.R.; SPEIT, G. Evaluation of the mutagenicity of the moluscicidal latex of Christ's Crown (Euphorbia milivarhislopii) in mammalian cells in vitro and in vivo. Mutation Research, v.368, p.15-20, 1996. 